\begin{tabular}{|c|c|c|}
\hline Beitr. Ent. & Keltern & ISSN $0005-805 \mathrm{X}$ \\
\hline $\mathbf{6 0}(2010) 1$ & S. $57-70$ & 31.07 .2010 \\
\hline
\end{tabular}

\title{
New and poorly known Epermeniidae from the Neotropical, Australasian, Oriental and Palaearctic Regions
}

\section{(Lepidoptera)}

With 41 figures

ReINHARD GAEDike

\section{Summary}

As the result of the study of Epermeniidae collected in the Neotropical, Australasian, Oriental and Palaearctic Regions, two species (Epermenia (Calotripis) brasiliana GAEDIKE \& BeCKer, 1989 and Epermenia (Cataplectica) sinica GAEDIKE, 1996) were newly recorded in three countries. Epermenia (Cataplectica) nepalica GAEDIKE, 1996 and Epermenia (Epermeniola) caledonica (GAEDIKE, 1981), previously only known from the types, were found a second time. The male genitalia of E. caledonica are described for the first time, and a new subgeneric placement established. The following taxa are described as new: Epermenia (Calotripis) boliviana sp. n., Epermenia (Calotripis) parastolidota sp. n., Epermenia (Epermeniola) davisi sp. n., Epermenia (Epermeniola) bicuspis sp. n., Epermenia (Cataplectica) pulchokicola sp. n., and Parochromolopis gielisi sp. n.

\section{Zusammenfassung}

Im Ergebnis der Untersuchung von Epermeniidae, die in der Neotropis, Australis, Orientalis und Paläarktis gesammelt wurden, wurden zwei Arten (Epermenia (Calotripis) brasiliana, GaEdiKe \& BeCKer, 1989, Epermenia (Cataplectica) sinica GAEDIKE, 1996) neu für drei Länder nachgewiesen. Epermenia (Cataplectica) nepalica GAEDIKE, 1996 wurde erstmals nach dem Typus wiedergefunden, wie auch Epermenia (Epermeniola) caledonica (GAEDIKE, 1981). Von letzterer war es möglich, erstmals die männlichen Genitalien zu beschreiben und eine neue subgenerische Zuordnung festzustellen. Die folgenden Taxa werden als neu beschrieben: Epermenia (Calotripis) boliviana sp. n., Epermenia (Calotripis) parastolidota sp. n., Epermenia (Epermeniola) davisi sp. n., Epermenia (Epermeniola) bicuspis sp. n., Epermenia (Cataplectica) pulchokicola sp. n., und Parochromolopis gielisi sp. $\mathbf{n}$.

\section{Key words}

Epermeniidae, Neotropics, Australasia, Oriental-Region, Palearctic-Region, new records, new species, new combination.

\section{Introduction}

In the past, through the courtesy of several colleagues, it was possible for me to study numerous hitherto undetermined Epermeniidae. As a result it is now possible to present new records of species previously only known from the type. It was possible to describe the male of one species for the first time together with a new combination. Additionally, six new species were established, which are described below. The material studied is deposited in the collections of several museums. 


\section{Abbreviations}

The abbreviations of the institutional collections in which the material studied is deposited, follow the list "Insect and Spider Collections of the World" from the Bishop Museum/Honolulu (http://hbs.bishopmuseum.org/codens).

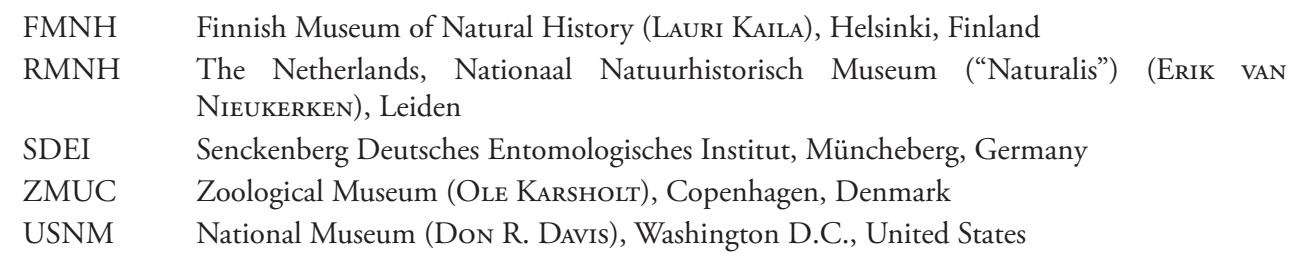

\section{Acknowledgements}

I am thankful to my colleagues for the courtesy which made it possible for me to study the material mentioned in this paper. I was able to sort out the specimens from the USNM during a visit in 1996, supported by the Short Term Visitor program. Special thanks go to Christian KuTzscher (SDEI) for making colour pictures, and to ANDrEw Liston (SDEI) for linguistic corrections.

\section{Systematics}

\section{Epermenia (Calotripis) boliviana sp. n.}

\section{Material:}

Holotype ơ , "Bolivia. Dept. Cochabamba 25 km NW Mizque, 2950 m, 16.-17.iv.1987, P. Arctander leg. Zool. Mus. Copenhagen;" "Gen.präp.[genitalia slide] Gaed.[IKe] Nr. 3647;" "Holotypus o", Epermenia (Calotripis) boliviana sp. n., det. R. GaEdike 2010;" ZMUC.

\section{Description (Fig. 1):}

Wingspan $19 \mathrm{~mm}$; head, palpi, thorax deep dark brown, antenna somewhat lighter; forewing deep dark brown, two tufts of raised scales (hardly visible on the holotype because the scales and ciliae are stuck together) at $1 / 3$ and $1 / 2$ at dorsum; on the cell below the first tuft and at $2 / 3$ each a little black dot, one side edged with cream scales; with no other pattern; hindwing creamy.

Male genitalia (Figs 10-12): Uncus long, thin, pointed; tegumen edged apically; valva with pointed bent ampulla, as long as cucullus, and distinct sclerotized border; sacculus with narrow top; phallus as long as valva, cornutus approximately a third of the length, with parallel sides, truncated apically.

Female genitalia: Unknown.

Etymology: Named after the country in which the species was collected.

\section{Remarks:}

The colouration makes the new species distinctive. 


\section{Epermenia (Calotripis) parastolidota sp. n.}

\section{Material:}

Holotype 우 “MEXICO: 5 mi. E. Tulancingo. Hgo. July 24, 1963, 7400' Ducкworth \& Davis;" "Gen.präp.[genitalia slide] GaEdIKe NR: 6355;" "Holotypus ㅇ, Epermenia (Calotripis) parastolidota sp. n. det. R. GaEdike 2010;” USNM.

\section{Description (Fig. 2):}

Wingspan $16 \mathrm{~mm}$; head from neck to the area below the palpi creamy, laterally brownish grey, palpi brownish grey, inner side lighter, tip of last segment creamy; thorax creamy, tegulae light brown; forewing creamy, with a pattern of brown and dark brown scales; two dark brown, nearly black, two tufts of raised scales at $1 / 3$ and $1 / 2$, an indication of a third tuft at $3 / 4$ at dorsum; on the cell below the first tuft and at 3/4 each a small dark dot; costa on the first fourth, a patch below the first tuft, and the apical fourth suffused with darker scales; cilia around apex dark brown, sickle-shaped; the dorsum from base to the first tuft creamy; nearly the whole wing is covered with creamy lines below the veins, the spaces are overlaid with darker or with light brown scales.

Male genitalia: Unknown.

Female genitalia (Fig. 13): Last sternite invaginated about range of ostium, ostium slightly funnel-shaped, strongly sclerotized, signum basally nearly triangular, with a long, thin, pointed prolongation.

Etymology: Named after the superficial similarity to E. stolidota (MEYrick, 1917).

\section{Remarks:}

Superficially similar to stolidota, but the size is distinctly smaller. Clearly distuingishable by the genitalia structure. The new species has a funnel-shaped ostium, contrasting with the ring-shaped ostium in stolidota, and with a larger signum.

\section{Epermenia (Calotripis) brasiliana GAEDIKE \& BECKER, 1989}

\section{Material:}

Argentina: 1 ơ, 3 ㅇ, Tucuman, $11 \mathrm{~km} \mathrm{~S}$ Tacanas, 28 km WSW Trancas, 800 m, 15.xi.1995, Neth. Ent. Exp. N-Arg. Sta. 13; 1 + , Tucuman, Alto de San Agustin ar Javier, 920 m, 15.i.1996, Neth. Ent. Exp. N-Arg. Sta. 43; 1 ㅇ, Tucuman, Alto de San Agustin, 1025 m, 2.ii.1996, Neth. Ent. Exp. N-Arg. Sta. 60; 1 \& , Salta, Camino de Cornissa, 1200 m, 12.xi.1995, Neth. Ent. Exp.

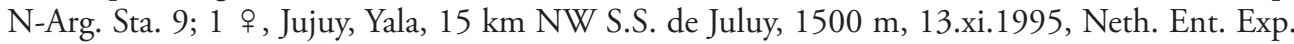
N-Arg. Sta. 11; RMNH: New country record.

Peru: 1 o $^{\star}$, Dept. Huánaco 15: 25 km NE Huánaco, Cordillera Carpish, Pattytrail, 2600 m, 8.10.ii.1987, leg. O. Karsholt; 1 o, Dept. Puno 56: 5 km E Limbani, 3000 m, 28.iii.1987, leg. O. KaRSHOLT; ZMUC: New country record.

\section{Epermenia (Epermeniola) caledonica (GAEDIKE, 1981), comb. n.}

\section{Material:}

New Caledonia: 6 o $^{\star}$, Mt. Dzumak, 760 m, 2202'S, 166²8'E 27-28 Feb. 1984, M. Pogue \& 
M. Epstein; USNM.; SDEI; 1 o, 1 , Mt. Panié, 250 meters 30 Oct. 1986, UV trap R. Brown

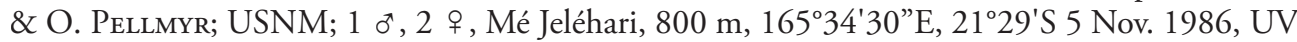

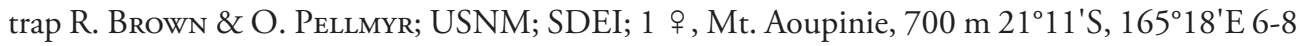
March 1984 M. Pogue; USNM: First records other than type.

The possibility to study the male genitalia of this species for the first time shows that caledonica belongs to the subgenus Epermeniola, and not to the subgenus Calotripis as was mentioned in the original description. The specimens are in better condition than the holotype, so that it is possible to provide an additional decription.

\section{Redescription (Figs 3-4):}

Wingspan 10 - $12 \mathrm{~mm}$; Head, palpi and thorax brown grey, antenna nearly as long as the lenght of the forewing, flagellum of the male ciliate, ciliae appr. 1.5 times longer than the diameter of the flagellum segments, flagellum of the female without ciliae. Forewing with tufts of raised black scales at $1 / 3,1 / 2,2 / 3$ and $3 / 4$ at dorsum, the last two tufts very small, partly only as an indication; on the cell, below the first tuft, and at $3 / 4$, each a black dot, the first is very small, often invisible, the second larger, elongated; costa basally and from $1 / 2$ to $3 / 4$ dark grey brown, other parts ot the costa creamy; apex dark grey brown too, fringes with two black sickle-shaped scale-lines; on the cell, on both sides of the second black dot a light brown area; hindwings grey.

Male genitalia (Figs 14-16): Uncus long, terminally blunt, tegumen proximally edged; valva with straight ampulla, rounded apically, border hardly more sclerotized, with numerous short bristles; sacculus with pointed top; cucullus clearly longer than ampulla; phallus 3/4 of the lenght of the valva, without cornuti.

Remarks:

Ciliate antennae of the males were hitherto unknown in the family.

\section{Epermenia (Epermeniola) davisi sp. n.}

\section{Material:}

Holotype $0^{\star}$, "TAIWAN: Ping Tung Co. Kenting Bot. Garden subtropical forest July 22-25, 1980, D. R. Davis, 260 m;" "Gen.präp.[genitalia slide] Gaedike NR. 5839;" "Holotypus o Epermenia (Epermeniola) davisi sp. n. det. R. GAEDIKe 2010;” USNM.

Paratype: 1 ㅇ, with same dates, “Gen.präp.[genitalia slide] GaEdike NR. 5840;”“"Paratypus 우 Epermenia (Epermeniola) davisi sp. n. det. R. GAEDIKe 2010;” USNM.

\section{Description (Fig. 5):}

Wingspan $11 \mathrm{~mm}$; head, palpi and scapus creamy, outside of palpi overlaid with some darker scales; antenna nearly as long as the forewing; thorax creamy, tegulae basally darker; forewing with two dark tufts of raised scales at $1 / 2$ and $2 / 3$ at dorsum; from base to the first tuft light creamy, following by a broad dark brown-grey triangular-shaped stripe from the first tuft to costa and along the costa up to $3 / 4$; the forewing below this area yellow, between the dark and the yellow area a clear white border with characteristic pattern (see fig. 5); apex black, between apex and the yellow area two short blackish stripes, edged whitish; fringes below apex with two short sickleshaped dark scale lines; hindwing grey.

Male genitalia (Figs 17-19): Uncus long, light curved, pointed, tegumen narrow; valva with short ampulla, apically curved upward, a narrow stronger sclerotized border, transtilla broad, truncated; 
from base of the transtilla oblique to the ventral edge a broad bristled strip; cucullus more than twice as long as ampulla, oval, rounded; phallus as long as the valva, without cornuti; anellus folded, basally curved.

Female genitalia (Figs 20-21): VIII sternit slightly invaginated, ductus bursae below the ostium with a ring-shaped sclrotization, corpus bursae wrinkeled, signum spoon-shaped, basally a stronger sclerotized strip, the edge light dentate.

Etymology: Named after Don R. DAvis, the collector of this new taxon.

\section{Remarks:}

The characteristic pattern of the forewing distuingishes the new species from all other known species in this subgenus.

\section{Epermenia (Epermeniola) bicuspis sp. n.}

\section{Material:}

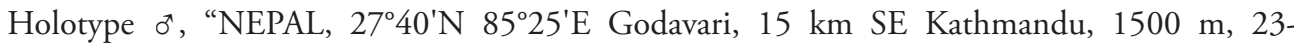
25.5.1996, Exp. A. Аlbrecht, O. Biström, K. Мikкola \& A. Wikberg;” "Gen.präp. [genitalia slide] GaEdike NR. 5792;" "Holotype o", Epermenia (Epermeniola) bicuspis sp. n. det. R. GAEDIKE 2010;" FMNH

\section{Description (Fig. 6):}

Wingspan $12 \mathrm{~mm}$; head, palpi, thorax brown grey, scales bicoloured light-dark, head below palpi and the inside of the palpi lighter; scapus with pecten; the outside of the palpi and the legs overlaid with numerous dark scales, the proximal end of the hind femur with ring-shaped black marking; forewing narrow, with two tufts of raised scales at $1 / 3$ and $1 / 2$ at dorsum, apically an indication of an additional tuft; on cell, below the second tuft and at 3/4 each a black dot, the second dot larger than the first dot; the area below the first tuft and the apical half of the forewing brown, along whole costa short dark stripes, before the apex a larger dark patch, on fringes two sickle-shaped lines of dark scales; hindwing grey.

Male genitalia (Figs 22-24): Uncus long, thin, pointed, tegumen broad, proximally with stronger sclerotized edge; valva with slightly curved ampulla, with distinctly stronger sclerotized border; sacculus with pointed top; cucullus longer than the ampulla; phallus longer than the valva, with two cornuti: the first one about half of the length, narrow, basally broader, proximally blunt, the second one stronger sclerotized as the first cornutus, short, consists of two pointed thorns, basally two very small additional thorns.

Female genitalia: Unknown.

Etymology: Named after the characteristically shaped cornutus.

\section{Remarks:}

The new species is superficially similar to the other members of the subgenus, but the structure of the genitalia (the cornutus) is a distinctive characteristic of this taxon. 


\section{Epermenia (Cataplectica) pulchokicola sp. n.}

\section{Material:}

Holotype ơ, "NEPAL, 2736'N 8525'E Mt. Pulchoki, 2500 m, 10.5.1996 Exp. A.Albrecht, O. Biström, K. Miккоla \& A.Wikberg;" “Gen.präp.[genitalia slide] Gaedike NR. 5834;" "Holotypus ơ , Epermenia (Cataplectica) pulchokicola sp. n. det. R. GAEDIKe 2010;" "Mus. Zool. HELSINKI Loan nr. L 97-4;” FMNH.

\section{Description (Fig. 7):}

Wingspan $17 \mathrm{~mm}$; head, and palpi brown-grey, inside of the palpi paler; tegulae and first half of the thorax also brown-grey, the second half of the thorax lighter brown; forewing with two tufts of raised black scales at dorsum at $1 / 3$ and $1 / 2$; on the end of the cell, at $3 / 4$, a small black dot, an indication of a second black dot on the cell below the first tuft; nearly the whole costa with a narrow row of dark grey scales; the area from the first tuft oblique to costa at $1 / 2$ to apex clay-coloured, the basal half of the forewing creamy, only below the base a clay coloured patch; on fringes a sickle-shaped line of dark scales; hindwing light shining.

Male genitalia (Fig. 25-27): Uncus long, narrow, rounded, tegumen narrow, proximally with stronger sclerotized edge; valva with a short blunt transtilla, ampulla slight curved, pointed, a little longer as the cucullus, the border hardly visible, sacculus with pointed, stronger sclerotized tip; phallus as long as valva, slight curved, cornutus appr. 3/4 of the length of phallus, basally rounded, apically pointed.

Female genitalia: Unknown.

Etymology: Named after the location (Mt. Pulchoki) at which the holotype was found.

\section{Remarks:}

The pattern of the forewing distinguishes the new species from E. nepalica, which is nearly unicolourous grey-brown. Clear differences are visible in the genitalia structure: E. pulchokicola with narrow, long uncus, valva with clear transtilla, a distinctly pointed tip of sacculus, cornutus about a half of the diameter of the phallus; E. nepalica with short, broader uncus, no clear transtilla, sacculus with smaller tip, cornutus nearly as broadas the diameter of the phallus.

\section{Epermenia (Cataplectica) sinica GAEDIKE, 1996}

\section{Material:}

1 ơ $^{\star}$ Nepal, 3 km SE Jomson Thinigaun, 2950 m, 7.viii.1996, leg. M. Fibiger; ZMUC: New country record.

\section{Epermenia (Cataplectica) nepalica GAEDIKE, 1996}

\section{Material:}

1 ㅇ, Nepal, Gandaki Tukuche, 2650 m, 5.viii.1996, leg. M. Fibiger; ZMUC: First record after type series. 


\section{Parochromolopis gielisi sp. n.}

\section{Material:}

Holotype ơ, "ARGENTINA, Jujuy, P.N. Calilegua, Mirador, 800 m, 20.xi.1995, rainforest, Neth. Ent. Exp. N-Arg. Sta. 14;" "Museum Lieden don. C. Gielis, Arg. Exp. 2004-ENT-63;" "Gen. präp. [genitalia slide] Gaedike NR. 6366;" "Holotypus ơ, Parochromolopis gielisi sp. n. det. R. GAedike 2010;” RMNH;

Paratypes: 2 \% , 1 specimen without abdomen, same dates; RMNH [2 specimens, one with slide NR. 6368]; SDEI [slide NR. 6365]

\section{Description (Figs 8-9):}

Wingspan 14 - $15 \mathrm{~mm}$; head and palpi brown, palpi long, straight, the proximal segment directed upward, the second segment covered with long (ca. twice as long as the diameter of the segment) grey brown scales, directed upward (see fig. 8); thorax brown, tegulae and tip of last thoracic segment overlaid with darker scales; forewing narrow, with tufts of raised scales at $1 / 3,1 / 2$ and $2 / 3$ at dorsum, the third tuft very small; costa basally with a distinct black patch, the basal third of the forewing lighter brown than the other part, forewing brown from the end of the first tuft to apex with a pattern of nearly black patches and stripes on the cell, apex brown, bordered with black stripe; fringes below the apex brown; hindwing grey.

Male genitalia (Fig. 28): Uncus long, pointed, tegumen edged basally and proximally; valva with a very long transtilla, costal edge proximally pointed, slightly longer than the rounded end of the valva; in the proximal half two pointed sclerotizations, somewhat hook-shaped, the first with a long rod-shaped sclerotization, parallel to costa, the second with a shorter bristled base; phallus appr. 1.5 times as long as the valva, narrowing apically from rounded base, cornutus a third of the length of the phallus, basally pointed, proximally truncate; anellus a large ring.

Female genitalia (Figs 29-30): Proximal edge of the VIII segment invaginated, with two rounded lobi lateral of ostium; nearly the whole ductus bursae strongly sclerotized with very small tubercles; corpus bursae with numerous semicircular sclerotizations, signum oval, edges dentate, with many rows of small thorns.

Etymology: Named after my colleague Cees Gielis, the collector of this new species.

\section{Remarks:}

The new species is clearly distinguishable by the characteristic shape of the palpi and the narrow forewing. The shape of the valva and the lobi on the VIII segment are distinct differences in the genitalia structures.

Author's address:

Dr. Reinhard Gaedike

Florusstraße 5

53225 Bonn

Germany

email: tinagma@msn.com
Subject editor:

Dr. W. MeY 


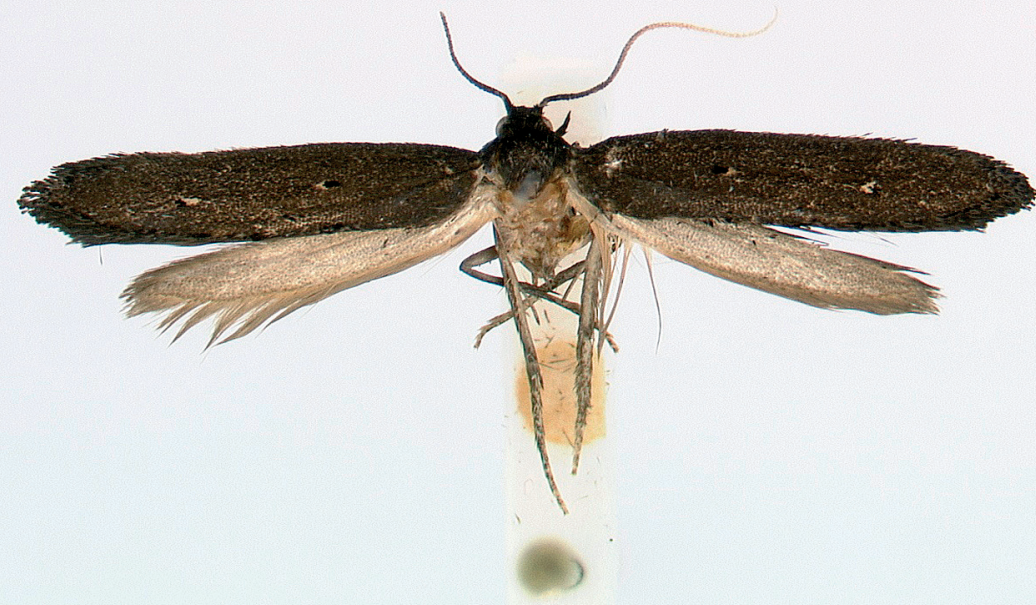

$2 \mathrm{~mm}$

Fig. 1: Epermenia (Calotripis) boliviana sp. $\mathrm{n}$.

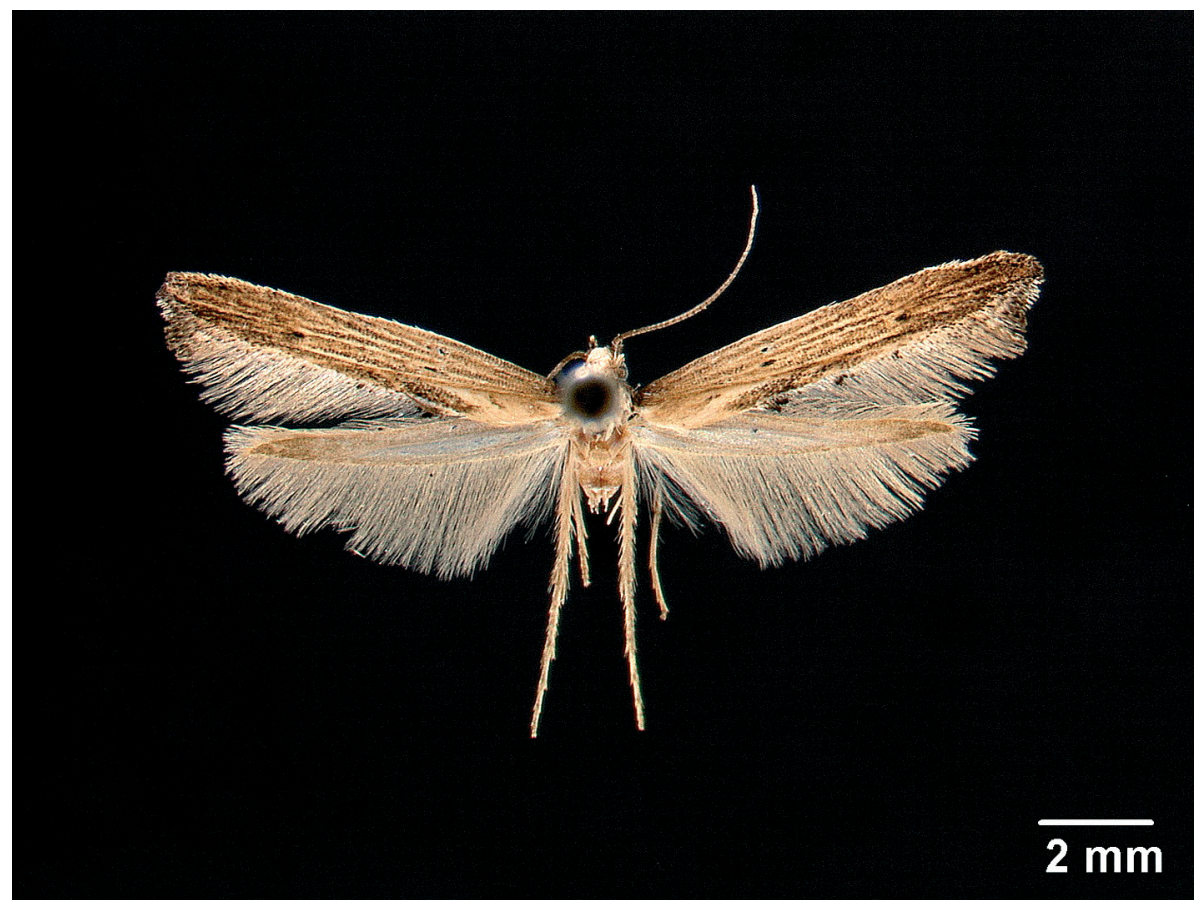

Fig. 2: Epermenia (Calotripis) parastolidota sp. n. 


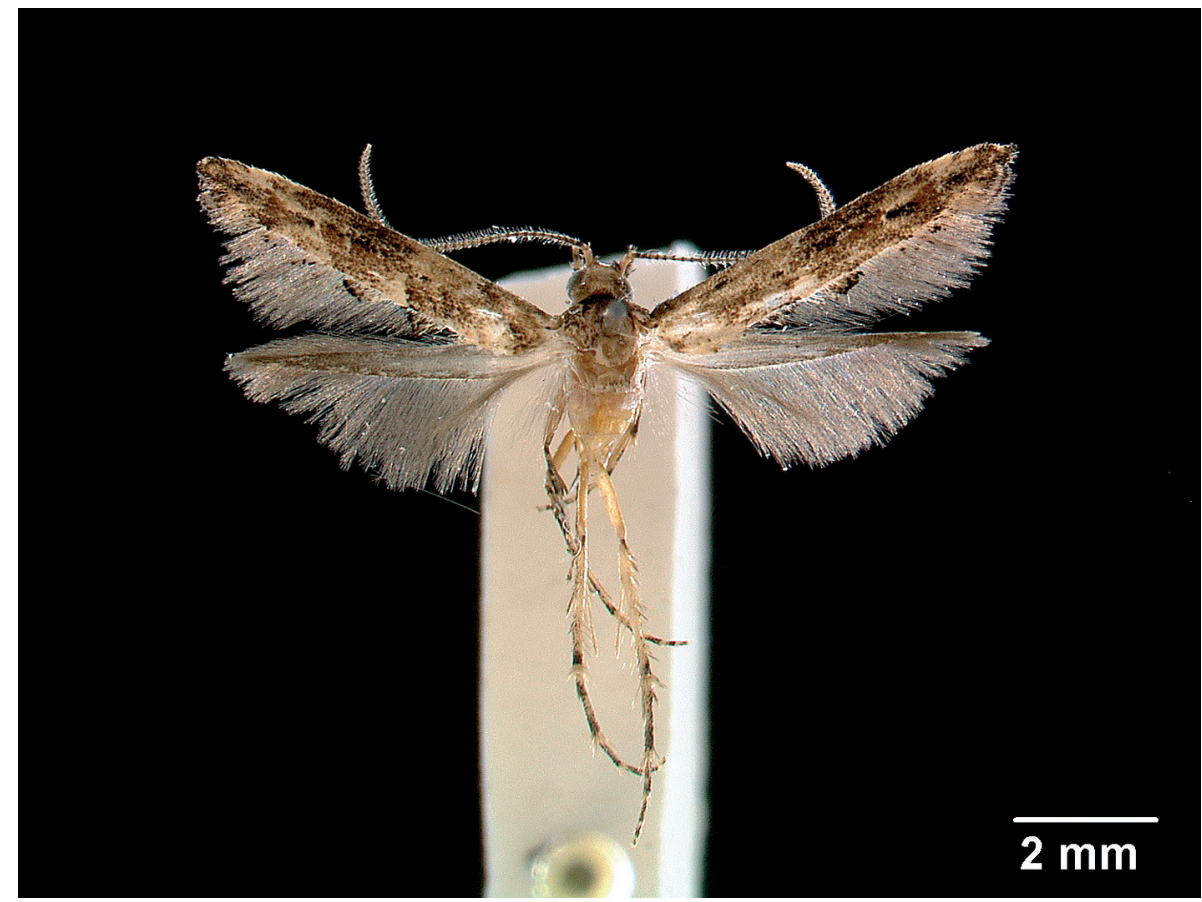

Fig. 3: Epermenia (Epermeniola) caledonica (GAEDIKE, 1981).

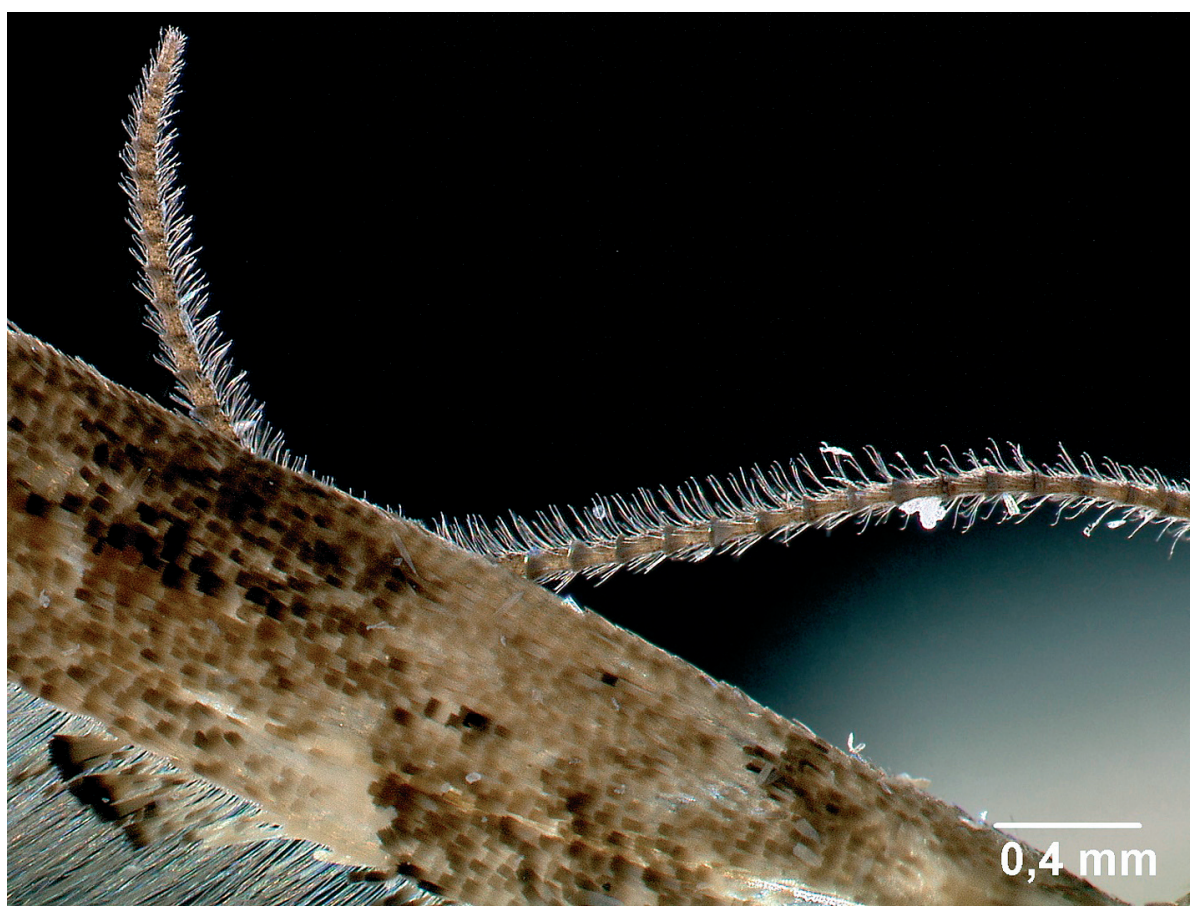

Fig. 4: Epermenia (Epermeniola) caledonica, male antenna. 


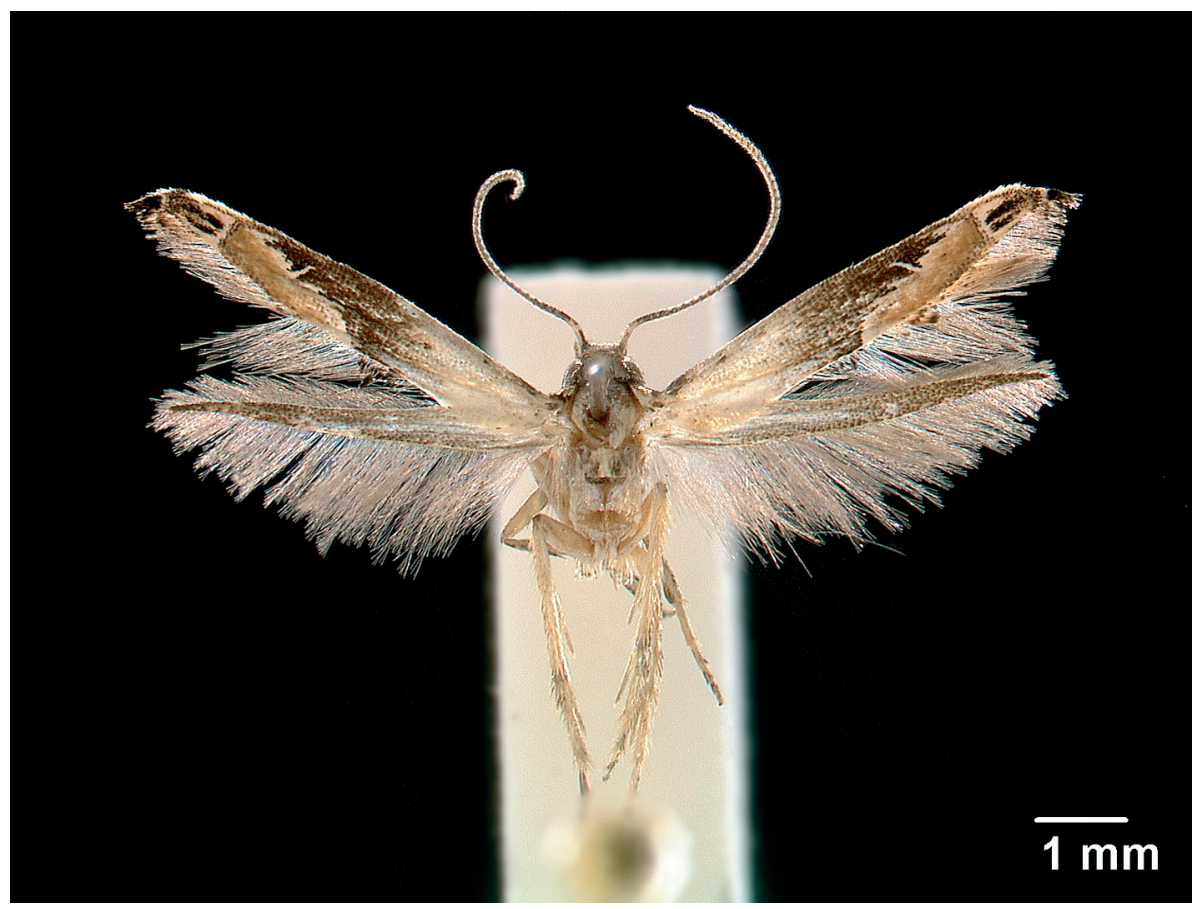

Fig. 5: Epermenia (Epermeniola) davisi sp. n.

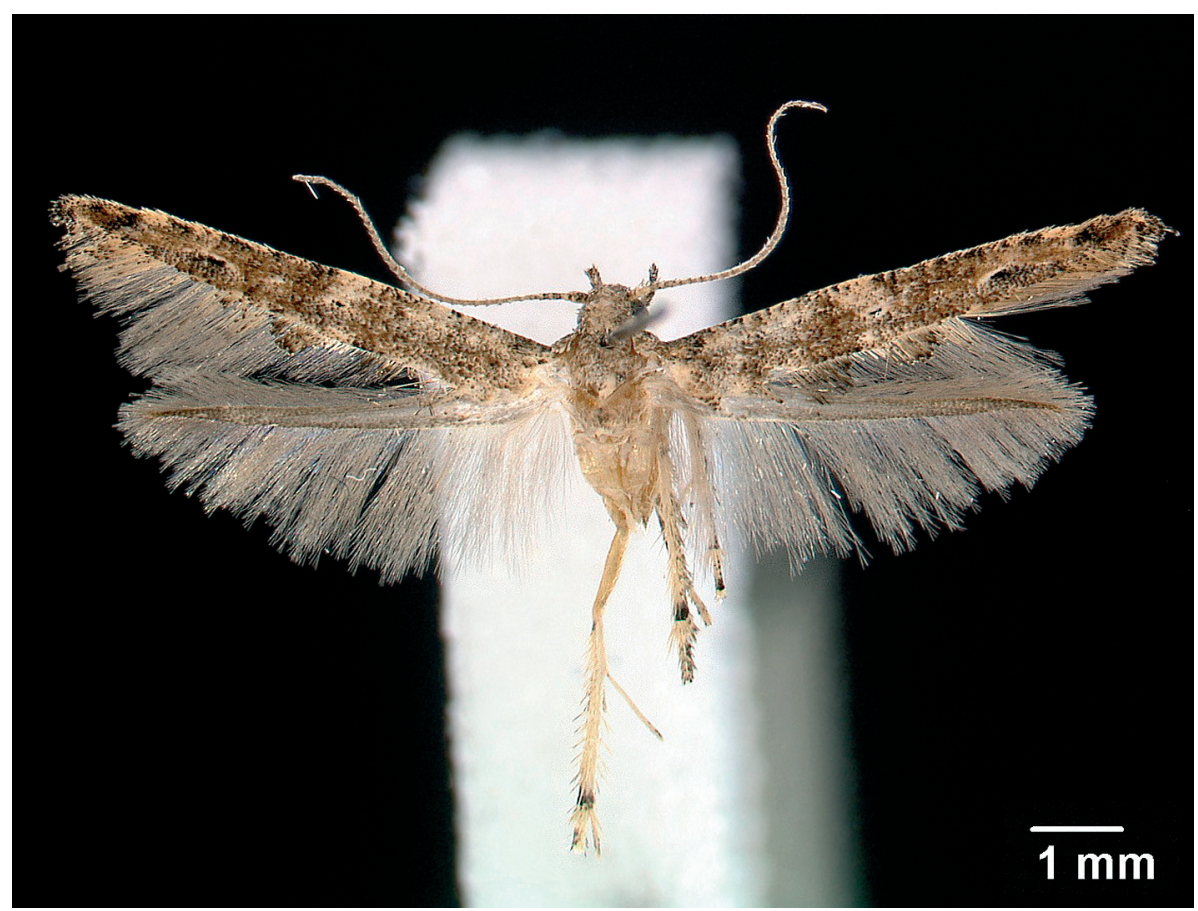

Fig. 6: Epermenia (Epermeniola) bicuspis sp. n. 


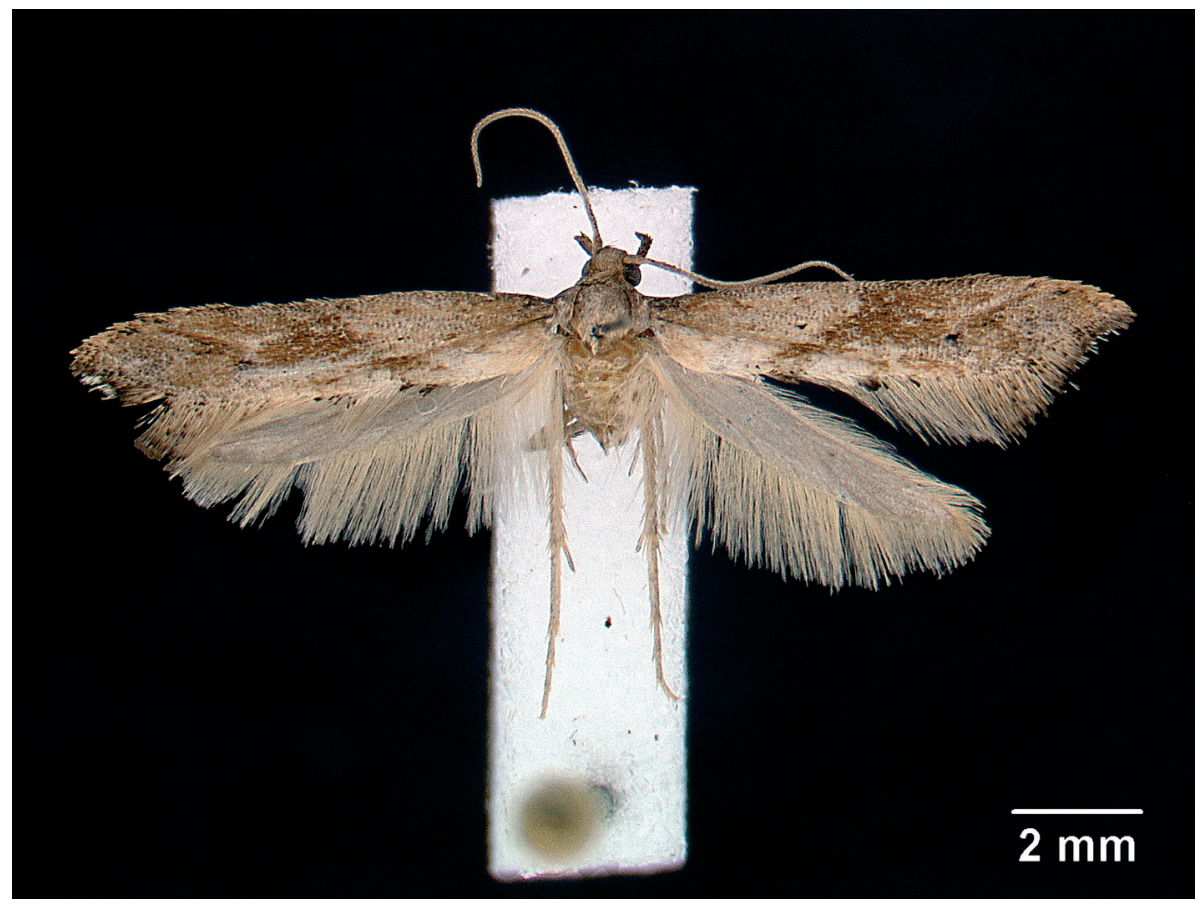

Fig. 7: Epermenia (Cataplectica) pulchokicola sp. n.

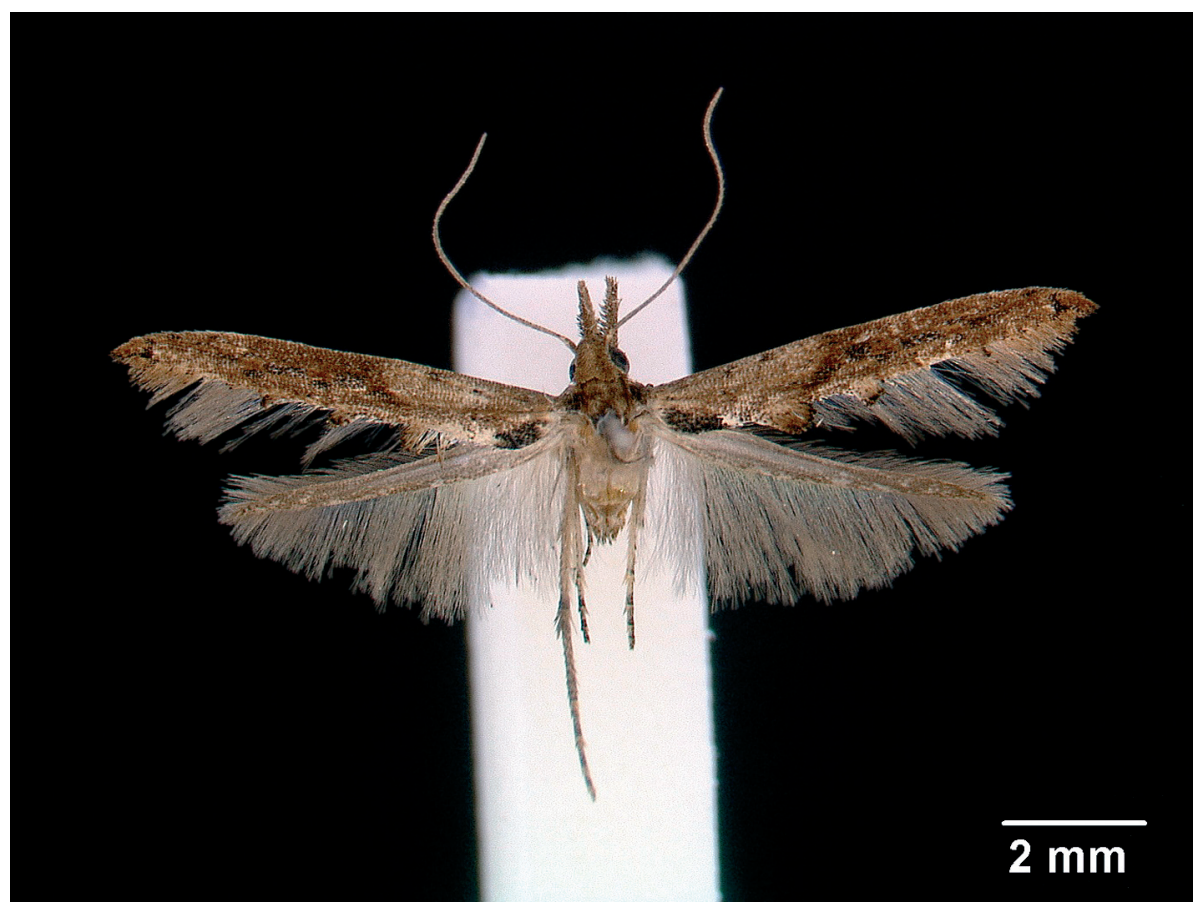

Fig. 8: Parochromolopis gielisi sp. n. 


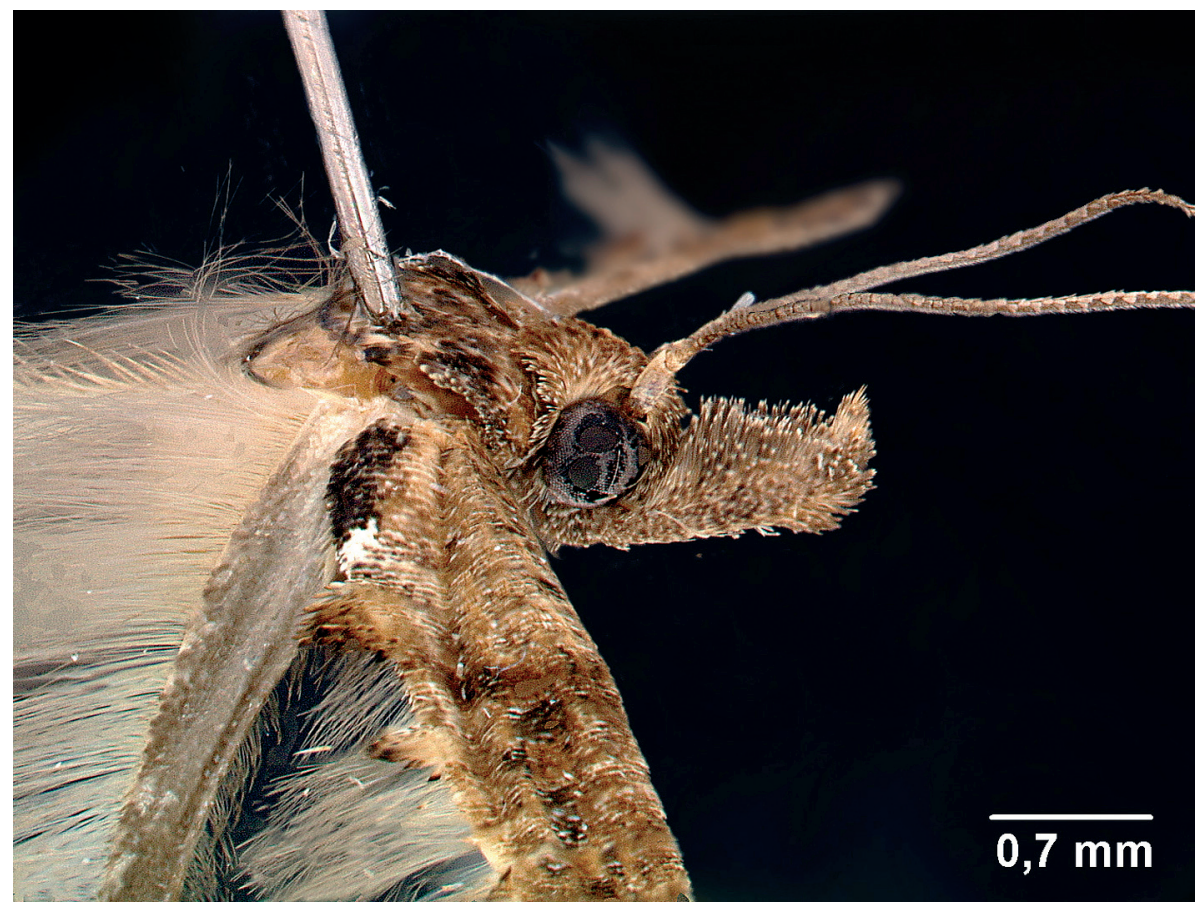

Fig. 9: Parochromolopis gielisi, palpi.
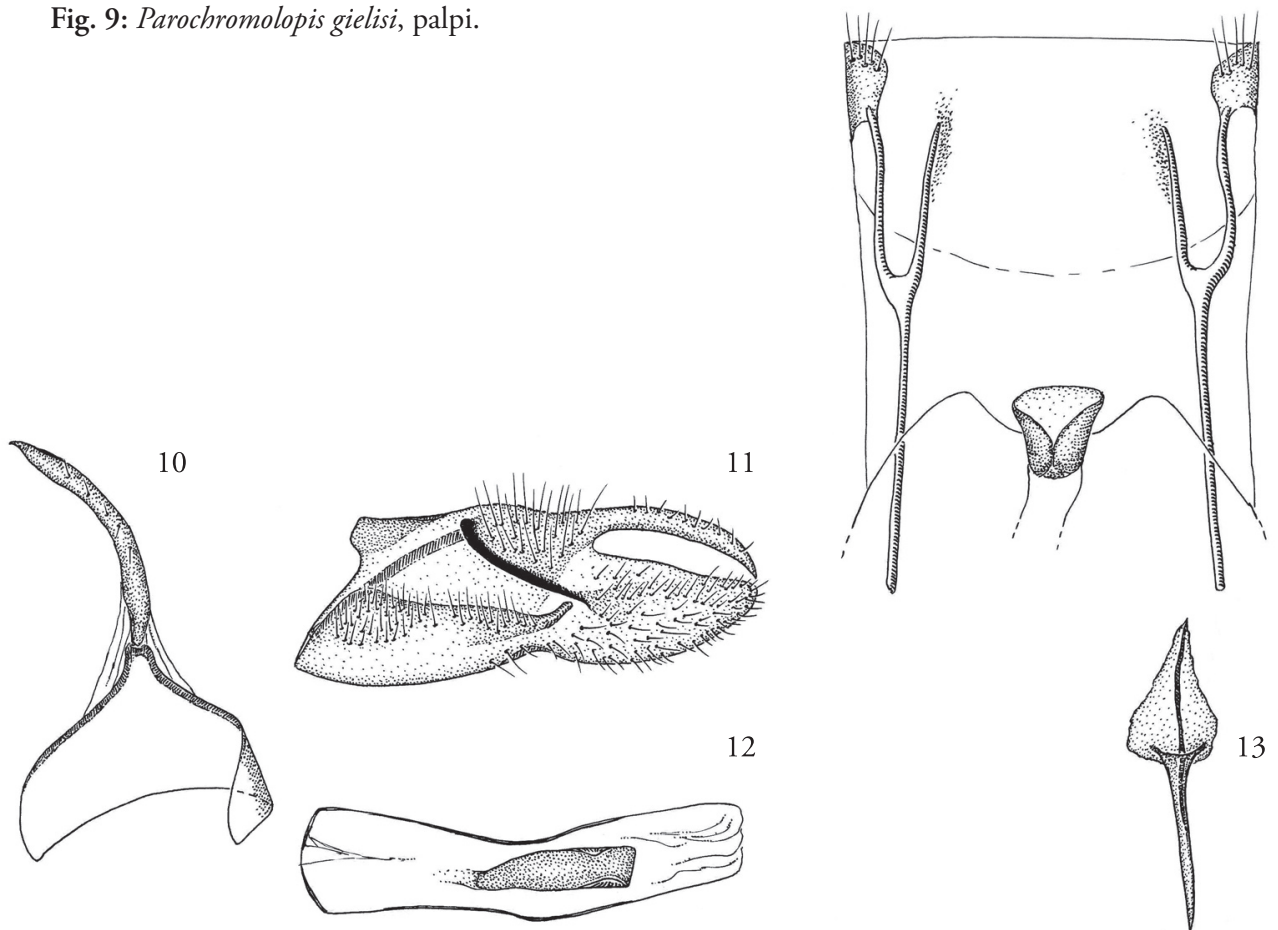

Figs 10-12: Epermenia (Calotripis) boliviana, ơ: (10 - uncustegumen; 11 - valva; 12 - phallus).

Fig. 13: Epermenia (Calotripis) parastolidota, ㅇ (signum separated). 

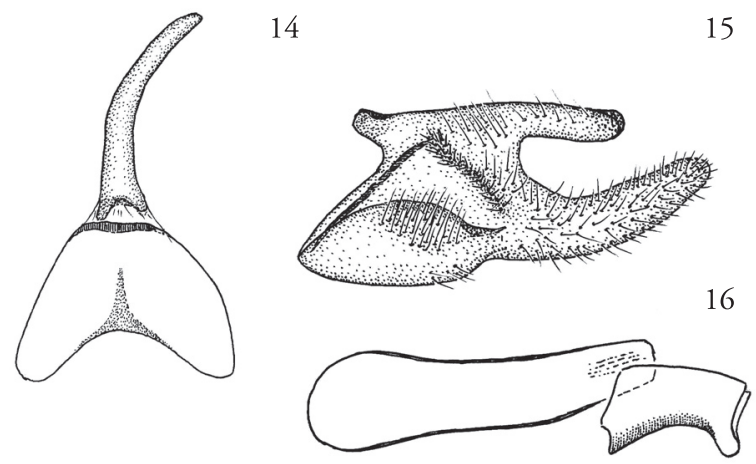

Figs 14-16: Epermenia (Epermeniola) caledonica, o ${ }^{\mathrm{T}}$ : (14 - uncus-tegumen; 15 - valva; 16 - phallus-anellus).
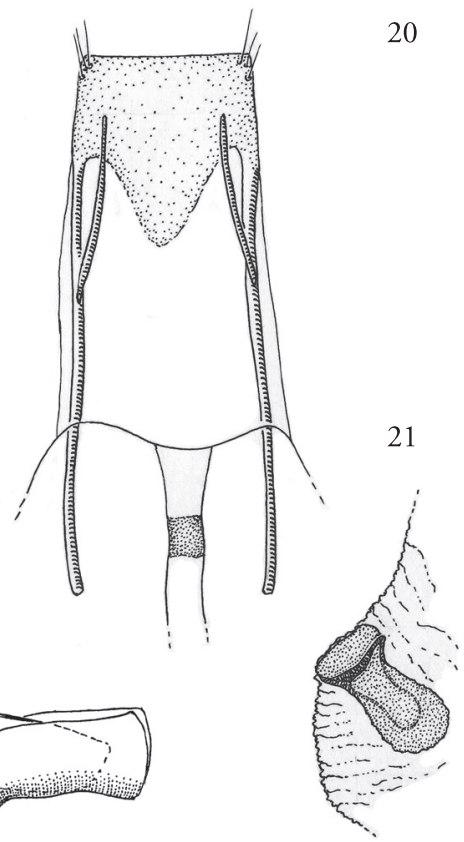

18
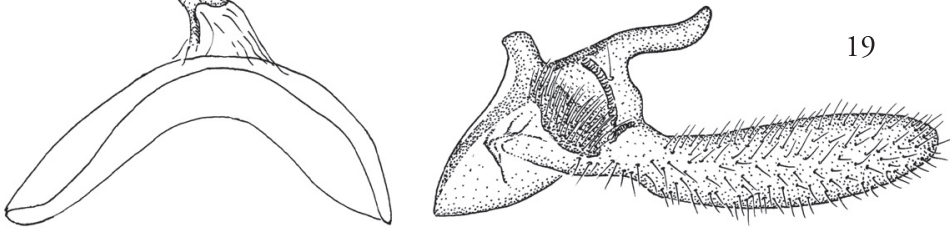

Figs 17-21: Epermenia (Epermeniola) davisi, ơ: (17 - uncus-tegumen; 18 - phallus-anellus; 19 - valva); 우 (20 - VIII segment; 21 - signum bursae).
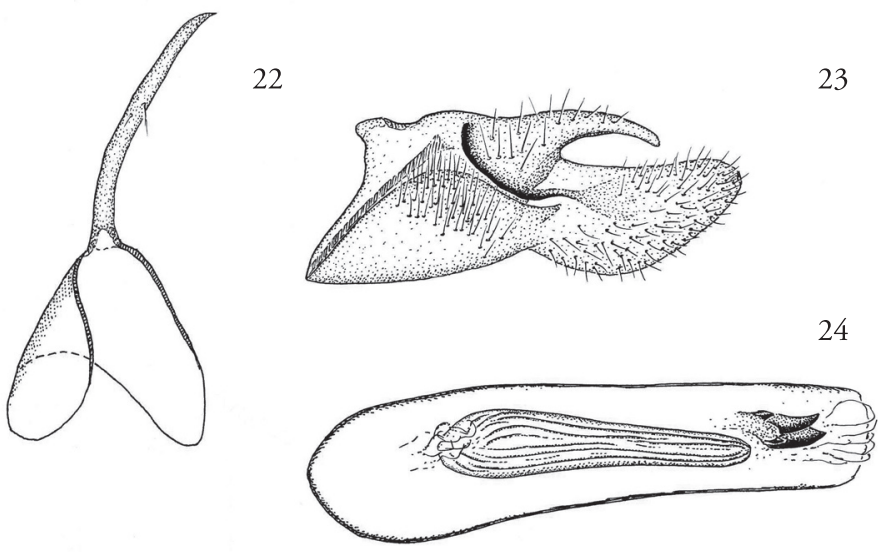

Figs 22-24: Epermenia (Epermeniola) bicuspis, ơ⿱: (22 - uncus-tegumen; 23 - valva; 24 - phallus). 


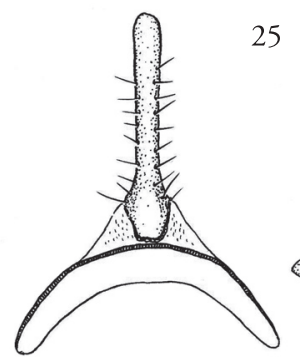

26

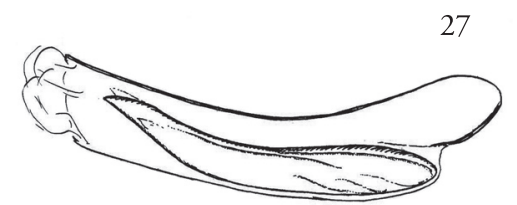

Figs 25-27: Epermenia (Cataplectica) pulchokicola, ơ: (25 - uncus-tegumen; 26 - valva; 27 - phallus).
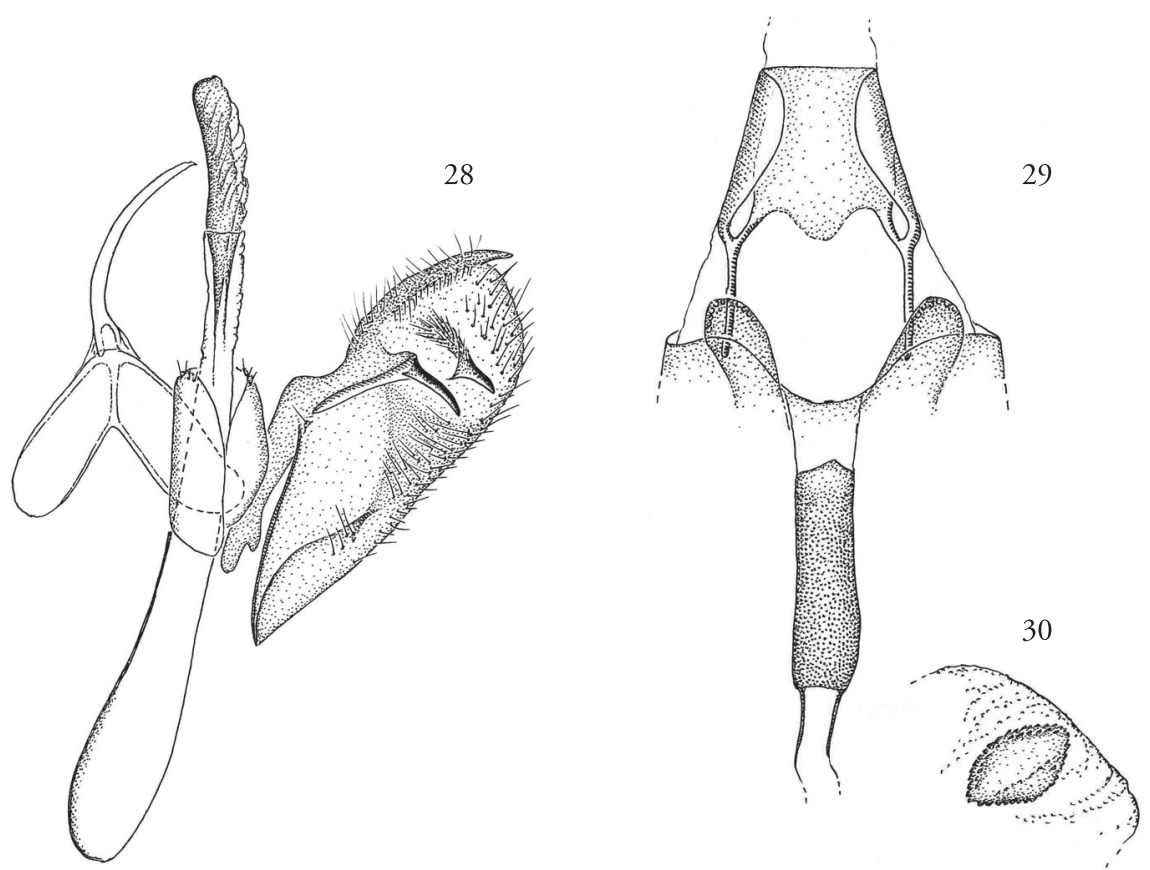

Figs 28-30: Parochromolopis gielisi, ơ: (28 - male genitalia, one valva removed); 우: (29 - VIII segment, ostium area; - 30 - signum bursae). 